\title{
Cooperative Game Theory Approach for Portfolio Sectoral Selection Before and After Malaysia General Elections: GE13 versus GE14
}

\author{
Muhammad Akram Ramadhan bin Ibrahim, Pah Chin Hee*, Mohd Aminul Islam, Hafizah Bahaludin
}

Department of Computational and Theoretical Sciences Kulliyyah of Science, International Islamic University Malaysia, Kuantan, Malaysia

DOI: $10.36348 /$ sjef.2020.v04i08.003 | Received: 30.07 .2020 | Accepted: 06.08.2020 | Published: 11.08 .2020

*Corresponding author: Pah Chin Hee

\section{Abstract}

The aim of this research is to provide a model for optimising the sectoral portfolio selection by using game theory during a general elections phase. We select stocks from Bursa Malaysia and calculate the payoff for each stock and its coalition sectors by averaging returns. The value of the game is at the same time the characteristic function of a multiple-player game which will be applied to obtain the Shapley value using the cooperative game theory approach for finding the optimal increment of the returns. We also compare the Shapley value percentages obtained for both periods of the $13^{\text {th }}$ Malaysia General Election (GE13) and $14^{\text {th }}$ Malaysia General Election (GE14) to indicate the impact of GE14 on investment. This research will lead to optimal portfolio selection before and after an election.

Keywords: Cooperative game theory, shapley value, portfolio.

Copyright @ 2020: This is an open-access article distributed under the terms of the Creative Commons Attribution license which permits unrestricted use, distribution, and reproduction in any medium for non-commercial use (NonCommercial, or CC-BY-NC) provided the original author and source are credited.

\section{INTRODUCTION}

An investment is the present commitment of money or other assets in the anticipation of reaping long term benefits in the future [1]. An investment portfolio is a collection of investment assets owned by investors. These investors can either be individual investors or institutional investors. The financial market is a trading marketplace that involves securities like equities, bonds and derivatives. The stock market encourages investors to allocate their capital in firms that have convincing prospects. A general election is an example of a volatile situation that affects investments. This research focuses on comparing the sectoral changes before and after general elections in Malaysia to determine their impact, if any.

Malaysia has undergone 14 episodes of general elections up to 2018. Before the $14^{\text {th }}$ General Election, the Barisan Nasional coalition had won all 13 previous elections. The last two general elections (GE13 and GE14) saw a particularly close competition between Barisan Nasional and Pakatan Rakyat which resulted in a higher chance for Pakatan Rakyat to win the election. After the dissolution of the Pakatan Rakyat, a new party was formed known as the Pakatan Harapan. Pakatan Harapan ultimately won a simple majority in parliament to form a new government in 2018. During the general elections in 2008 and 2013, fluctuations in the market showed that political uncertainty has a significance influence. However, the general election years of 1995 1999 and 2004 showed that it had no effect on stock market returns [2].

The decision in constructing a sectoral portfolio is the choice of which securities to hold within each asset class. The allocation of financial assets is a problem faced by investors in the country as they need to choose their optimal portfolios to maintain a good performance in the financial markets especially pre and post general elections. The investor's objective is choosing a portfolio that can maximise returns at certain risk conditions especially during elections and perform it in abundant in type and number instead of choosing the best investment options individually which may be subject to more risk conditions.

As financial markets are highly competitive, investors will find ways to increase their gains. One of the methods is by diversifying their assets. Diversification means that various assets are held in the portfolio. Diversifying investments leads to a higher expected return and lower standard deviations. In the classical way, investors believe that putting several stocks in their portfolio will lead to a decrease in risk without any consideration of the returns for these stocks. 
As suggested by the classical approach, investors should invest in many types of stocks that have higher expected returns at a given level of risk and will cooperate to perform better in the market. Since various approaches have been studied to solve the investment portfolio selection problem, this uncertainty was also studied by Harry Markowitz [3] in 1952, where his article titled Portfolio Selection brought up the modern portfolio theory that an investment's return and risk should not be calculated alone but by using an overview of the entire portfolio.

There are two fundamental characteristics in the financial market, the first is competition among market players and the second is uncertainty. This means that a player's game will be affected by the other players' total market performance behaviour with the uncertainty conditions of the financial market. Based on these two essential fundamental characteristics, it can be implemented in the game theory part that refers to the optimal decision making by players in evaluating and calculating the payoff of other players by using mathematics.

Game theory can be divided into two categories; noncooperative and cooperative games. A cooperative game is a kind of game in which there are binding agreements among players that unite together to achieve a higher payoff instead of acting individually. In this research, the considerations are sectors as players and the cooperation between sectors to maximise their collective payoffs. Therefore, this cooperative game approach can be used to compare the impact before and after the $13^{\text {th }}$ and $14^{\text {th }}$ Malaysian general elections. Hence, the main problem of the research is to provide a model for optimising the sectoral portfolio selection by using game theory during a general elections phase.

The findings of this research will contribute to the game theory study in Malaysia, especially during political changes. This research also gives contribution in investment theory field on how to suggest a sectoral portfolio using game theory approach when there is a political change.

\section{LITERATURE REVIEW}

Game theory is one of the mathematical tools that has been used in determining the competitiveness between players. It comes with a formal analytical framework and a number of mathematical instruments to study the complex intersections among rational players [4]. A player's behaviour in choosing a strategy will depend on the other players' selection of strategies. All the chosen strategies not only give positive or negative payoffs individually but also influences the other players' payoffs simultaneously.

There are two types of games: cooperative game or non-cooperative game. Non-cooperative game is a game where the players make a decision on their own strategies to maximise their payoff. This representation of game can be seen as players in the market with conflicts of interests that influence each other. Cooperative game is a game that has binding agreements among players through agreements or negotiations. Since the games basically are played under uncertainty and risky conditions, there are some aspects in common between financial markets and the games.

The investor and the market can be two players opposed to each other in the market. This idea can be modelled in a zero-sum game. The condition of the market is not solely dependent on the overall market since there are some other factors such as political and economic conditions, and social behaviour changes in the market.

There are indications that show the strong relationship between political stability and stock market performance. The hypothesis on the effect of political elections on the stock market has been studied by a number of papers with significant findings which reflect the economic performance of the country. There was a study by Floros [5] on the influence of Greece's political elections on the Athens Stock Exchange by using the ordinary least squares models on the preelection and post-election periods.

In addition, the findings of Abidin et al., [6] provide evidence that there is no election effect on New Zealand's stock market except in 2002, where there was an increment in market returns after the election rather than prior to the election. However, there was an election effect on the political cycle when the nominal returns on the market index increased when the National Party formed the government seats in contrast to the situation during a Labour Party victory. Smales [7] examined the effect of the Australian federal election cycle's political uncertainty on the financial market uncertainty. The empirical results showed that the Australian election uncertainty has a significant effect on financial market uncertainty.

A paper written by Lehkonen and Heimonen [8] examined the effects of democracy and political risk on the stock market. There is significant evidence that the stock market returns of 49 emerging countries are affected by political uncertainty. A previous study showed that there was a significant election effect on the Malaysian stock market's volatility during the $12^{\text {th }}$ and $13^{\text {th }}$ general elections [9]. In addition, another paper by Liew and Rowland [2] found that each election had a different effect on the daily returns of the FBMKLCI for every election studied in their research. In $40 \%$ of the time the stock market reacted positively before the elections, whereas $60 \%$ of the time the market reacted positively after the elections. Chavali et al., [10] Examined the effect of elections on the stock market 
and analysed the market reaction towards the same political party wins for the second time. They used market model event study with sample period from 2014 to 2019 that involved 31 companies listed in Bombay Stock Exchange. In years 2014 and 2019, an event window of 82 days was taken with 39 days prior to the event and 42 days post event and 83 days was taken with 41 days prior to the event and 41 days post event respectively. The findings revealed that even the same political party wins for the second time, the impact on the stock market is not same between any two elections.

Most of the previous studies used statistical analysis and were unable to suggest which sectors showed changes during both phases. In addition, Habip Kocak [11] conducted a research on the portfolio partnership optimality return. The results showed that the return was allocated according to the weight of each stock in the portfolio using the method of Shapley value by scaling the payoffs to avoid negative return values. Tataei et al., [12] investigated ways of maximising the outcome of the player and the model of optimal portfolio selection using the cooperative game theory by shifting the payoff to avoid negative values. The study found that the proposed portfolio by using cooperative game theory had a better performance most of the time as they try to defeat the market through coalition. Nesrin Ozkan [13] examined portfolio optimisation in Borsa Istanbul by using a game theoretic approach to analyse the relative performances of sectoral portfolios. He found that the model can be used in portfolio optimisation since the technology sector has the highest return with the lowest portfolio concentration and its relative performance is higher compared to the other sectors in the research. Slišković \& Škrinjarić [14] also used Shapley value solution concept to evaluate the risk of each individual asset in a portfolio by using the Zagreb Stock Exchange data. The risk used as a cost needs to be divided fairly among individual asset that depends on the contribution to total risk of a portfolio.

Recently, cooperative game has enticed interest with its ability to guide investors' preference on investment options with different risk groups. Therefore, this study will use the game theory approach with significant results on sector allocation. Based on this, the research will be focusing on the changes which occurred before and after the Malaysian general elections where Pakatan Harapan won while studying the sectoral changes in the FBM30.

\section{DATA AND METHODOLOGY}

The Financial Times Stock Exchange Bursa Malaysia Kuala Lumpur Composite Index (FBMKLCI) is the largest stock exchange in Malaysia. The FBMKLCI is a share index of the 30 companies listed on Bursa Malaysia with the highest market capitalisation. The data used in this study only consists of daily closing price returns of 14 stocks included in the FBMKLCI. All the data are obtained from Datastream.

The aim of this research is to observe three sectoral portfolio changes before and after the general elections that will be generated by the Shapley value solution concept in Bursa Malaysia. The first three main sectors in FBMKLCI that maintain the groups listed during GE13 and GE14 are financial services sector, consumer products and services sector, and telecommunications and media sector. The analysis is run for a period of six months before and after the general elections.

Table-1: Study period

\begin{tabular}{|l|l|l|}
\hline General Election 13 & Period Date & Trading Day \\
\hline Before & $1 / 11 / 2012-3 / 5 / 2013$ & 132 \\
\hline After & $6 / 5 / 2013-29 / 11 / 2013$ & 150 \\
\hline General Election 14 & Period Date & Trading Day \\
\hline Before & $1 / 11 / 2017-8 / 5 / 2018$ & 135 \\
\hline After & $10 / 5 / 2018-30 / 11 / 2018$ & 147 \\
\hline
\end{tabular}

There are three sectors involve which are determined as follows:

A : Financial services

B : Consumer products and services

$\mathrm{C}$ : Telecommunications and media
The nature player (FBMKLCI) has two strategies which are determined as follows:

P1 : Period before general election

P2 : Period after general election 
Table-2: Players and strategies

\begin{tabular}{|l|l|l|l|}
\hline Players/Sectors & Strategies & Name & Code \\
\hline Player A : Financial Services & A1 & AMMB Holdings Berhad & $1015 . \mathrm{KL}$ \\
\cline { 2 - 4 } & A2 & CIMB Group Holdings Berhad & $1023 . \mathrm{KL}$ \\
\cline { 2 - 4 } & $\mathrm{A} 3$ & Hong Leong Bank Berhad & $5819 . \mathrm{KL}$ \\
\cline { 2 - 4 } & A4 & Hong Leong Financial Berhad & $1082 . \mathrm{KL}$ \\
\cline { 2 - 4 } & A5 & Malayan Banking Berhad & $1155 . \mathrm{KL}$ \\
\cline { 2 - 4 } & A6 & Public Bank Berhad & $1295 . \mathrm{KL}$ \\
\cline { 2 - 4 } & A7 & RHB Capital Berhad & $1066 . \mathrm{KL}$ \\
\hline Player B : Consumer Products and Services & B1 & PPB Group Bhd & $4065 . \mathrm{KL}$ \\
\cline { 2 - 4 } & B2 & Genting Bhd & $3182 . \mathrm{KL}$ \\
\cline { 2 - 4 } & B3 & Genting Malaysia Bhd & $4715 . \mathrm{KL}$ \\
\cline { 2 - 4 } & $\mathrm{B} 4$ & Petronas Dagangan Bhd & $5681 . \mathrm{KL}$ \\
\hline Player C : Telecommunications and Media & $\mathrm{C} 1$ & Axiata Group Berhad & $6888 . \mathrm{KL}$ \\
\cline { 2 - 4 } & $\mathrm{C} 2$ & Digi.Com Berhad & $6947 . \mathrm{KL}$ \\
\cline { 2 - 4 } & $\mathrm{C} 3$ & Maxis Berhad & $6012 . \mathrm{KL}$ \\
\hline
\end{tabular}

This research follows the methodology applied in Kocak's paper [11] in applying cooperative game theory approach towards sectoral portfolio selection. The model of this research is zero sum game where the players are between investors and the stock market, and a cooperative game in a static game model. The daily prices of each stock is used to calculate the return of each stock. The returns are expressed in logarithmic form as follows:

$$
R_{t}=\ln \left(P_{t}\right)-\ln \left(P_{t-1}\right)
$$

Where,

$R_{t}$ is the daily return of the stock at time $t$,

$P_{t}$ is the daily stock price at time $t$,

$P_{t-1}$ is the daily stock price at time $t-1$.

Annual average return of each stocks are calculated as following:

$$
\bar{R}=\frac{\sum_{t=1}^{n} R_{t}}{n}
$$

Where,

$\bar{R}$ is the average return,

$R_{t}$ is the daily return of the stock, $n$ is the number of trading days.
The return prices for each stock are calculated by using equation (1) and the average returns are formed from equation (2). The average returns have positive and negative returns. Hence, to avoid negative payoff values during the cooperation calculation in the Shapley value solution concept, all the values are shifted in the payoff matrices for all sectors, by subtracting them with the minimum value among all sectors. The shifted average return values are then evaluated in Production and Operations Management Quantitative Methods (POM - QM) for Windows software to get the value of games.

\section{Mathematical Model of Cooperative Game}

A characteristic function game is given by a pair $(N, v)$, where $N$ is the total number of players and $v: 2^{[N]} \rightarrow \mathbb{R}$ is a characteristic function which maps every coalition of players to a payoff. Let $S$ be the each cooperation in $N$ and define $v(S)$ as the value obtained from the cooperation. The cooperation formed at least has to guarantee that the values that are obtained by coalitions, defined as superadditivity therefore increasing payoff. The worth of the cooperative is equal to at least the worth of each of them acting alone. Superadditivity is defined as follows:

$$
\begin{aligned}
& v\left(S_{1} \cup S_{2}\right) \supset\left\{x \in \mathbb{R}^{\left|S_{1} \cup S_{2}\right|} /\left(x_{i}\right)_{i \in S_{1}} \in v\left(s_{1}\right),\left(x_{j}\right)_{j \in S_{1}} \in v\left(S_{2}\right)\right\} \forall S_{1} \subset N, \forall S_{2} \subset N, S_{1} \cap S_{2}=\emptyset \\
& v\left(S_{1} \cup S_{2}\right) \geq v\left(S_{1}\right)+v\left(S_{2}\right) \forall S_{1} \subset N, \forall S_{2} \subset N, S_{1} \cap S_{2}=\emptyset
\end{aligned}
$$

The values obtained from the cooperation will be distributed by using Shapley value to observe the changes occuring before and after both general

$$
\mu_{i}(v)=\sum_{i \in S} \frac{(N-|S|) !(|S|-1) !}{N !}[v(S)-v(S \backslash\{i\})] i \in S
$$

and Shapley vector is as follows:

$$
v(N)=\sum_{i=1}^{N} \mu_{i}(v)
$$

elections. Let $\mu_{i}(v)$ be the Shapley value of player $i$. The Shapley value equation is as follows: 
The values of the game that obtained from (POM - QM) for Windows software are distributed by using Shapley value equation (3) to evaluate the expected marginal contribution for each sector. The value of the game is then used to get the percentages allocation to each sector during GE13 and GE14.

The payoff matrices below are divided into two Malaysia general election phases as follows:

GE13 $: 13^{\text {th }}$ general election.

Table-3: Payoff matrix structured for player $A$

\begin{tabular}{|l|l|l|}
\hline & P1 & P2 \\
\hline A1 & $1.36 \mathrm{E}-03$ & $1.80 \mathrm{E}-03$ \\
\hline A2 & $1.05 \mathrm{E}-03$ & $1.05 \mathrm{E}-03$ \\
\hline A3 & $8.72 \mathrm{E}-04$ & $9.86 \mathrm{E}-04$ \\
\hline A4 & $2.36 \mathrm{E}-03$ & $1.29 \mathrm{E}-03$ \\
\hline A5 & $1.53 \mathrm{E}-03$ & $1.20 \mathrm{E}-03$ \\
\hline A6 & $1.28 \mathrm{E}-03$ & $1.86 \mathrm{E}-03$ \\
\hline A7 & $1.94 \mathrm{E}-03$ & $4.05 \mathrm{E}-04$ \\
\hline
\end{tabular}

Table-4: Payoff matrix structured for player B

\begin{tabular}{|l|l|l|}
\hline & P1 & P2 \\
\hline B1 & $5.71 \mathrm{E}-04$ & $2.17 \mathrm{E}-03$ \\
\hline B2 & $1.99 \mathrm{E}-03$ & $1.22 \mathrm{E}-03$ \\
\hline B3 & $1.18 \mathrm{E}-03$ & $2.09 \mathrm{E}-03$ \\
\hline B4 & $1.45 \mathrm{E}-03$ & $3.05 \mathrm{E}-03$ \\
\hline
\end{tabular}

Table-5: Payoff matrix structured for player C

\begin{tabular}{|l|l|l|}
\hline & P1 & P2 \\
\hline C1 & $1.15 \mathrm{E}-03$ & $1.19 \mathrm{E}-03$ \\
\hline C2 & $0.00 \mathrm{E}+00$ & $1.44 \mathrm{E}-03$ \\
\hline C3 & $8.39 \mathrm{E}-04$ & $1.34 \mathrm{E}-03$ \\
\hline
\end{tabular}

The payoff matrices above are solved in QM for Windows software, the values of game are as follow $v(\{A\})=0.00166, v(\{B\})=0.00181, v(\{C\})=0.00115$

The payoff matrices for coalitions formed by players $\mathrm{A}$ and $\mathrm{B}$, players $\mathrm{A}$ and $\mathrm{C}$, players $\mathrm{B}$ and $\mathrm{C}$ and players $\mathrm{A}, \mathrm{B}$ and $\mathrm{C}$ are given below.

Table-6: Payoff matrix structured for coalition of players $A$ and $B$

\begin{tabular}{|l|l|l|}
\hline & P1 & P2 \\
\hline A1B1 & $1.93 \mathrm{E}-03$ & $3.97 \mathrm{E}-03$ \\
\hline A1B2 & $3.35 \mathrm{E}-03$ & $3.03 \mathrm{E}-03$ \\
\hline A1B3 & $2.54 \mathrm{E}-03$ & $3.89 \mathrm{E}-03$ \\
\hline A1B4 & $2.81 \mathrm{E}-03$ & $4.85 \mathrm{E}-03$ \\
\hline A2B1 & $1.62 \mathrm{E}-03$ & $3.22 \mathrm{E}-03$ \\
\hline A2B2 & $3.04 \mathrm{E}-03$ & $2.27 \mathrm{E}-03$ \\
\hline A2B3 & $2.23 \mathrm{E}-03$ & $3.13 \mathrm{E}-03$ \\
\hline A2B4 & $2.50 \mathrm{E}-03$ & $4.09 \mathrm{E}-03$ \\
\hline A3B1 & $1.44 \mathrm{E}-03$ & $3.16 \mathrm{E}-03$ \\
\hline A3B2 & $2.86 \mathrm{E}-03$ & $2.21 \mathrm{E}-03$ \\
\hline A3B3 & $2.05 \mathrm{E}-03$ & $3.07 \mathrm{E}-03$ \\
\hline A3B4 & $2.32 \mathrm{E}-03$ & $4.03 \mathrm{E}-03$ \\
\hline A4B1 & $2.93 \mathrm{E}-03$ & $3.46 \mathrm{E}-03$ \\
\hline
\end{tabular}

\begin{tabular}{|l|l|l|}
\hline A4B2 & $4.35 \mathrm{E}-03$ & $2.52 \mathrm{E}-03$ \\
\hline A4B3 & $3.54 \mathrm{E}-03$ & $3.38 \mathrm{E}-03$ \\
\hline A4B4 & $3.81 \mathrm{E}-03$ & $4.34 \mathrm{E}-03$ \\
\hline A5B 1 & $2.10 \mathrm{E}-03$ & $3.37 \mathrm{E}-03$ \\
\hline A5B2 & $3.52 \mathrm{E}-03$ & $2.42 \mathrm{E}-03$ \\
\hline A5B3 & $2.70 \mathrm{E}-03$ & $3.29 \mathrm{E}-03$ \\
\hline A5B4 & $2.97 \mathrm{E}-03$ & $4.25 \mathrm{E}-03$ \\
\hline A6B1 & $1.85 \mathrm{E}-03$ & $4.03 \mathrm{E}-03$ \\
\hline A6B2 & $3.27 \mathrm{E}-03$ & $3.08 \mathrm{E}-03$ \\
\hline A6B3 & $2.45 \mathrm{E}-03$ & $3.94 \mathrm{E}-03$ \\
\hline A6B4 & $2.72 \mathrm{E}-03$ & $4.90 \mathrm{E}-03$ \\
\hline A7B1 & $2.51 \mathrm{E}-03$ & $2.58 \mathrm{E}-03$ \\
\hline A7B2 & $3.93 \mathrm{E}-03$ & $1.63 \mathrm{E}-03$ \\
\hline A7B3 & $3.11 \mathrm{E}-03$ & $2.49 \mathrm{E}-03$ \\
\hline A7B 4 & $3.38 \mathrm{E}-03$ & $3.45 \mathrm{E}-03$ \\
\hline
\end{tabular}

Table-7: Payoff matrix structured for coalition of players $A$ and $C$

\begin{tabular}{|c|c|c|}
\hline & P1 & $\mathbf{P 2}$ \\
\hline 8 & 5 & ( \\
\hline & & \\
\hline & $20 \mathrm{E}-03$ & $.15 \mathrm{E}-03$ \\
\hline & 2 & \\
\hline & 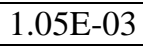 & .40 \\
\hline & $89 \mathrm{E}$ & .39 \\
\hline & & \\
\hline & 72 & 2.42 \\
\hline & & \\
\hline $\mathrm{C} 1$ & 52 & 2.48 \\
\hline & 3 & \\
\hline & 20 & $2.64 \mathrm{E}$ \\
\hline & 3 & $2.39 \mathrm{E}-03$ \\
\hline & 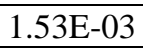 & $2.64 \mathrm{E}-03$ \\
\hline 3 & 375 & $2.54 \mathrm{E}-03$ \\
\hline & $.43 \mathrm{I}$ & $3.05 \mathrm{E}-03$ \\
\hline & $1.28 \mathrm{E}-03$ & $3.29 \mathrm{E}-03$ \\
\hline & 2.12 & $3.20 \mathrm{E}-03$ \\
\hline & $3.09 \mathrm{E}$ & $1.60 \mathrm{E}-03$ \\
\hline & $1.94 \mathrm{E}$ & \\
\hline A7C3 & $2.78 \mathrm{E}-03$ & $1.75 \mathrm{E}-03$ \\
\hline
\end{tabular}

Table-8: Payoff matrix structured for coalition of players $B$ and $C$

\begin{tabular}{|l|l|l|}
\hline & P1 & P2 \\
\hline B1C1 & $1.72 \mathrm{E}-03$ & $3.36 \mathrm{E}-03$ \\
\hline B1C2 & $5.71 \mathrm{E}-04$ & $3.61 \mathrm{E}-03$ \\
\hline B1C3 & $1.41 \mathrm{E}-03$ & $3.51 \mathrm{E}-03$ \\
\hline B2C1 & $3.14 \mathrm{E}-03$ & $2.41 \mathrm{E}-03$ \\
\hline B2C2 & $1.99 \mathrm{E}-03$ & $2.66 \mathrm{E}-03$ \\
\hline B2C3 & $2.83 \mathrm{E}-03$ & $2.56 \mathrm{E}-03$ \\
\hline B3C1 & $2.33 \mathrm{E}-03$ & $3.28 \mathrm{E}-03$ \\
\hline B3C2 & $1.18 \mathrm{E}-03$ & $3.52 \mathrm{E}-03$ \\
\hline B3C 3 & $2.01 \mathrm{E}-03$ & $3.43 \mathrm{E}-03$ \\
\hline B4C1 & $2.60 \mathrm{E}-03$ & $4.24 \mathrm{E}-03$ \\
\hline B4C2 & $1.45 \mathrm{E}-03$ & $4.48 \mathrm{E}-03$ \\
\hline B4C3 & $2.28 \mathrm{E}-03$ & $4.39 \mathrm{E}-03$ \\
\hline
\end{tabular}


Table-9: Payoff matrix structured for coalition of players $A, B$ and $C$

\begin{tabular}{|c|c|c|}
\hline & P1 & P2 \\
\hline A1B1C1 & $3.08 \mathrm{E}-03$ & $5.17 \mathrm{E}-03$ \\
\hline A1B1C2 & & 8 \\
\hline A1B1C3 & $2.77 \mathrm{E}-03$ & $5.32 \mathrm{E}-03$ \\
\hline $\mathrm{A} 1 \mathrm{~B} 2 \mathrm{C} 1$ & $4.50 \mathrm{E}-03$ & $4.22 \mathrm{E}-03$ \\
\hline $\mathrm{A} 1 \mathrm{~B} 2 \mathrm{C} 2$ & $3.35 \mathrm{E}-03$ & $4.46 \mathrm{E}-03$ \\
\hline A1B2C3 & $4.19 \mathrm{E}-03$ & $4.37 \mathrm{E}-03$ \\
\hline A1B3C1 & $3.69 \mathrm{E}-03$ & $5.08 \mathrm{E}-03$ \\
\hline A1B3C2 & $2.54 \mathrm{E}-03$ & $5.33 \mathrm{E}-03$ \\
\hline A1B3C3 & \begin{tabular}{|c|}
$3.38 \mathrm{E}-03$ \\
\end{tabular} & \\
\hline A1B4C1 & $3.96 \mathrm{E}-03$ & \\
\hline A1B4C2 & $2.81 \mathrm{E}-03$ & $6.29 \mathrm{E}-03$ \\
\hline A1B4C3 & \begin{tabular}{|c|}
$3.65 \mathrm{E}-03$ \\
\end{tabular} & $6.19 \mathrm{E}-03$ \\
\hline $\mathrm{A} 2 \mathrm{~B} 1 \mathrm{C} 1$ & $2.77 \mathrm{E}-03$ & $4.41 \mathrm{E}-03$ \\
\hline A2B1C2 & $1.62 \mathrm{E}-03$ & $4.65 \mathrm{E}-03$ \\
\hline A2B1C3 & \begin{tabular}{|l|}
$2.46 \mathrm{E}-03$ \\
\end{tabular} & $4.56 \mathrm{E}-03$ \\
\hline $\mathrm{A} 2$ & 4.1 & E-03 \\
\hline $\mathrm{C} 2$ & 3.0 & \\
\hline $\mathrm{A} 2 \mathrm{~B} 2 \mathrm{C} 3$ & $3.88 \mathrm{E}-03$ & $3.61 \mathrm{E}-03$ \\
\hline $\mathrm{A} 2 \mathrm{~B} 3 \mathrm{C} 1$ & $3.38 \mathrm{E}-03$ & $4.32 \mathrm{E}-03$ \\
\hline $\mathrm{A} 2 \mathrm{~B} 3 \mathrm{C} 2$ & $2.23 \mathrm{E}-03$ & $4.57 \mathrm{E}-03$ \\
\hline & 3.0 & -03 \\
\hline $\mathrm{A} 2 \mathrm{I}$ & 3.6 & -03 \\
\hline $\mathrm{C} 2$ & 2.5 & -03 \\
\hline $4 \mathrm{C} 3$ & 3.3 & -03 \\
\hline A3B1C1 & $2.59 \mathrm{E}-03$ & $4.35 \mathrm{E}-03$ \\
\hline A3B1C2 & $1.44 \mathrm{E}-03$ & $4.59 \mathrm{E}-03$ \\
\hline & & \\
\hline $\mathrm{A} 3 \mathrm{H}$ & 4.0 & 3.4 \\
\hline $\mathrm{A} 3 \mathrm{~F}$ & 2.8 & -03 \\
\hline $2 \mathrm{C} 3$ & 3.7 & -03 \\
\hline A3B3C1 & $3.20 \mathrm{E}-03$ & $4.27 \mathrm{E}-03$ \\
\hline A3B3C2 & $2.05 \mathrm{E}-03$ & $4.51 \mathrm{E}-03$ \\
\hline & & \\
\hline & 3.4 & 5.2 \\
\hline A3B4C2 & 2.3 & $5.47 \mathrm{E}-03$ \\
\hline A3B4C3 & $3.16 \mathrm{E}-03$ & $5.37 \mathrm{E}-03$ \\
\hline A4B1C1 & \begin{tabular}{|l|}
$4.09 \mathrm{E}-03$ \\
\end{tabular} & $4.66 \mathrm{E}-03$ \\
\hline A4B1C2 & $2.93 \mathrm{E}-03$ & $4.90 \mathrm{E}-03$ \\
\hline A4I & & $4.81 \mathrm{E}$ \\
\hline & & $3.71 \mathrm{E}-03$ \\
\hline $\mathrm{A} 4$ & 4.3 & 3.9 \\
\hline A4B2C3 & $5.19 \mathrm{E}-03$ & $3.86 \mathrm{E}-03$ \\
\hline A4B3C1 & \begin{tabular}{|l}
$4.69 \mathrm{E}-03$ \\
\end{tabular} & $4.57 \mathrm{E}-03$ \\
\hline A4B3C2 & $3.54 \mathrm{E}-03$ & $4.82 \mathrm{E}-03$ \\
\hline A4B3C3 & $4.38 \mathrm{E}-03$ & $4.72 \mathrm{E}-03$ \\
\hline & & $5.53 \mathrm{E}-03$ \\
\hline & & $5.78 \mathrm{E}-03$ \\
\hline A4B4C3 & \begin{tabular}{|l}
$4.65 \mathrm{E}-03$ \\
\end{tabular} & $5.68 \mathrm{E}-03$ \\
\hline $\mathrm{A} 5 \mathrm{~B} 1 \mathrm{C} 1$ & $3.25 \mathrm{E}-03$ & $4.56 \mathrm{E}-03$ \\
\hline A5B1C2 & $2.10 \mathrm{E}-03$ & $4.81 \mathrm{E}-03$ \\
\hline A5B1C3 & $2.94 \mathrm{E}-03$ & $4.71 \mathrm{E}-03$ \\
\hline $\mathrm{A} 5 \mathrm{~B} 2 \mathrm{C} 1$ & $4.67 \mathrm{E}-03$ & $3.62 \mathrm{E}-03$ \\
\hline A5B2C2 & $3.52 \mathrm{E}-03$ & $3.86 \mathrm{E}-03$ \\
\hline A5B2C3 & $4.35 \mathrm{E}-03$ & $3.77 \mathrm{E}-03$ \\
\hline A5B3C1 & $3.85 \mathrm{E}-03$ & $4.48 \mathrm{E}-03$ \\
\hline
\end{tabular}

\begin{tabular}{|l|l|l|}
\hline A5B3C2 & $2.70 \mathrm{E}-03$ & $4.73 \mathrm{E}-03$ \\
\hline A5B3C3 & $3.54 \mathrm{E}-03$ & $4.63 \mathrm{E}-03$ \\
\hline A5B4C1 & $4.12 \mathrm{E}-03$ & $5.44 \mathrm{E}-03$ \\
\hline A5B4C2 & $2.97 \mathrm{E}-03$ & $5.68 \mathrm{E}-03$ \\
\hline A5B4C3 & $3.81 \mathrm{E}-03$ & $5.59 \mathrm{E}-03$ \\
\hline A6B1C1 & $3.00 \mathrm{E}-03$ & $5.22 \mathrm{E}-03$ \\
\hline A6B1C2 & $1.85 \mathrm{E}-03$ & $5.46 \mathrm{E}-03$ \\
\hline A6B1C3 & $2.69 \mathrm{E}-03$ & $5.37 \mathrm{E}-03$ \\
\hline A6B2C1 & $4.42 \mathrm{E}-03$ & $4.27 \mathrm{E}-03$ \\
\hline A6B2C2 & $3.27 \mathrm{E}-03$ & $4.51 \mathrm{E}-03$ \\
\hline A6B2C3 & $4.11 \mathrm{E}-03$ & $4.42 \mathrm{E}-03$ \\
\hline A6B3C1 & $3.60 \mathrm{E}-03$ & $5.13 \mathrm{E}-03$ \\
\hline A6B3C2 & $2.45 \mathrm{E}-03$ & $5.38 \mathrm{E}-03$ \\
\hline A6B3C3 & $3.29 \mathrm{E}-03$ & $5.29 \mathrm{E}-03$ \\
\hline A6B4C1 & $3.88 \mathrm{E}-03$ & $6.09 \mathrm{E}-03$ \\
\hline A6B4C2 & $2.72 \mathrm{E}-03$ & $6.34 \mathrm{E}-03$ \\
\hline A6B4C3 & $3.56 \mathrm{E}-03$ & $6.24 \mathrm{E}-03$ \\
\hline A7B1C1 & $3.66 \mathrm{E}-03$ & $3.77 \mathrm{E}-03$ \\
\hline A7B1C2 & $2.51 \mathrm{E}-03$ & $4.01 \mathrm{E}-03$ \\
\hline A7B1C3 & $3.35 \mathrm{E}-03$ & $3.92 \mathrm{E}-03$ \\
\hline A7B2C1 & $5.08 \mathrm{E}-03$ & $2.82 \mathrm{E}-03$ \\
\hline A7B2C2 & $3.93 \mathrm{E}-03$ & $3.06 \mathrm{E}-03$ \\
\hline A7B2C 3 & $4.77 \mathrm{E}-03$ & $2.97 \mathrm{E}-03$ \\
\hline A7B3C1 & $4.27 \mathrm{E}-03$ & $3.68 \mathrm{E}-03$ \\
\hline A7B3C2 & $3.11 \mathrm{E}-03$ & $3.93 \mathrm{E}-03$ \\
\hline A7B3C3 & $3.95 \mathrm{E}-03$ & $3.83 \mathrm{E}-03$ \\
\hline A7B4C1 & $4.54 \mathrm{E}-03$ & $4.64 \mathrm{E}-03$ \\
\hline A7B4C2 & $3.38 \mathrm{E}-03$ & $4.89 \mathrm{E}-03$ \\
\hline A7B4C3 & $4.22 \mathrm{E}-03$ & $4.79 \mathrm{E}-03$ \\
\hline
\end{tabular}

The optimal game values are obtained as follow: $v(\{A, B\})=0.00393, v(\{A, C\})=0.00284, v(\{B, C\})$ $=0.00297, v(\{A, B, C\})=0.00509$

Based on the values of the game from the payoff matrices in Tables 3 to 9, the characteristic functions are calculated and tabulated in Table-10. The characteristic funcions of the game designed for coalitions among player A, player B and player $\mathrm{C}$ are shown in the table below:

Table-10: Characteristic function

\begin{tabular}{|c|l|}
\hline Characteristic Function & Value \\
\hline$v(\{\varnothing\})$ & 0.00000 \\
\hline$v(\{A\})$ & 0.00166 \\
\hline$v(\{B\})$ & 0.00181 \\
\hline$v(\{C\})$ & 0.00115 \\
\hline$v(\{A B\})$ & 0.00393 \\
\hline$v(\{A C\})$ & 0.00284 \\
\hline$v(\{B C\})$ & 0.00297 \\
\hline$v(\{A B C\})$ & 0.00509 \\
\hline
\end{tabular}

GE14 : $14^{\text {th }}$ general election. 
Table-11: Payoff matrix structured for player $\mathrm{A}$

\begin{tabular}{|l|l|l|}
\hline & P1 & P2 \\
\hline A1 & $2.80 \mathrm{E}-03$ & $4.76 \mathrm{E}-03$ \\
\hline A2 & $4.71 \mathrm{E}-03$ & $2.61 \mathrm{E}-03$ \\
\hline A3 & $4.99 \mathrm{E}-03$ & $4.46 \mathrm{E}-03$ \\
\hline A4 & $4.79 \mathrm{E}-03$ & $3.95 \mathrm{E}-03$ \\
\hline A5 & $4.92 \mathrm{E}-03$ & $2.95 \mathrm{E}-03$ \\
\hline A6 & $4.99 \mathrm{E}-03$ & $4.13 \mathrm{E}-03$ \\
\hline A7 & $4.11 \mathrm{E}-03$ & $3.81 \mathrm{E}-03$ \\
\hline
\end{tabular}

Table-12: Payoff matrix structured for player $B$

\begin{tabular}{|l|l|l|}
\hline & P1 & P2 \\
\hline B1 & $4.82 \mathrm{E}-03$ & $4.50 \mathrm{E}-03$ \\
\hline B2 & $3.46 \mathrm{E}-03$ & $1.70 \mathrm{E}-03$ \\
\hline B3 & $3.84 \mathrm{E}-03$ & $0.00 \mathrm{E}+00$ \\
\hline B4 & $4.56 \mathrm{E}-03$ & $3.68 \mathrm{E}-03$ \\
\hline
\end{tabular}

Table-13: Payoff matrix structured for player $\mathrm{C}$

\begin{tabular}{|l|l|l|}
\hline & P1 & P2 \\
\hline C1 & $3.70 \mathrm{E}-03$ & $1.28 \mathrm{E}-03$ \\
\hline C2 & $3.22 \mathrm{E}-03$ & $3.29 \mathrm{E}-03$ \\
\hline C3 & $3.27 \mathrm{E}-03$ & $3.74 \mathrm{E}-03$ \\
\hline
\end{tabular}

The payoff matrices above are solved in QM for Windows software, the values of game are as follows:

$v(\{A\})=0.00452, v(\{B\})=0.0045, v(\{C\})=0.00334$

The payoff matrices for coalitions formed by players $\mathrm{A}$ and $\mathrm{B}$, players $\mathrm{A}$ and $\mathrm{C}$, players $\mathrm{B}$ and $\mathrm{C}$ and players $\mathrm{A}, \mathrm{B}$ and $\mathrm{C}$ are given below.

Table-14: Payoff matrix structured for coalition of players $A$ and $B$

\begin{tabular}{|l|l|l|}
\hline & P1 & P2 \\
\hline A1B1 & $7.63 \mathrm{E}-03$ & $9.27 \mathrm{E}-03$ \\
\hline A1B2 & $6.27 \mathrm{E}-03$ & $6.46 \mathrm{E}-03$ \\
\hline A1B3 & $6.64 \mathrm{E}-03$ & $4.76 \mathrm{E}-03$ \\
\hline A1B4 & $7.36 \mathrm{E}-03$ & $8.45 \mathrm{E}-03$ \\
\hline A2B1 & $9.53 \mathrm{E}-03$ & $7.12 \mathrm{E}-03$ \\
\hline A2B2 & $8.17 \mathrm{E}-03$ & $4.31 \mathrm{E}-03$ \\
\hline A2B3 & $8.55 \mathrm{E}-03$ & $2.61 \mathrm{E}-03$ \\
\hline A2B4 & $9.26 \mathrm{E}-03$ & $6.30 \mathrm{E}-03$ \\
\hline A3B1 & $9.82 \mathrm{E}-03$ & $8.96 \mathrm{E}-03$ \\
\hline A3B2 & $8.45 \mathrm{E}-03$ & $6.16 \mathrm{E}-03$ \\
\hline A3B3 & $8.83 \mathrm{E}-03$ & $4.46 \mathrm{E}-03$ \\
\hline A3B4 & $9.55 \mathrm{E}-03$ & $8.14 \mathrm{E}-03$ \\
\hline A4B1 & $9.61 \mathrm{E}-03$ & $8.45 \mathrm{E}-03$ \\
\hline A4B2 & $8.25 \mathrm{E}-03$ & $5.65 \mathrm{E}-03$ \\
\hline A4B3 & $8.63 \mathrm{E}-03$ & $3.95 \mathrm{E}-03$ \\
\hline A4B4 & $9.35 \mathrm{E}-03$ & $7.63 \mathrm{E}-03$ \\
\hline A5B1 & $9.74 \mathrm{E}-03$ & $7.46 \mathrm{E}-03$ \\
\hline A5B2 & $8.38 \mathrm{E}-03$ & $4.65 \mathrm{E}-03$ \\
\hline
\end{tabular}

\begin{tabular}{|l|l|l|}
\hline A5B3 & $8.76 \mathrm{E}-03$ & $2.95 \mathrm{E}-03$ \\
\hline A5B4 & $9.48 \mathrm{E}-03$ & $6.64 \mathrm{E}-03$ \\
\hline A6B1 & $9.81 \mathrm{E}-03$ & $8.63 \mathrm{E}-03$ \\
\hline A6B2 & $8.45 \mathrm{E}-03$ & $5.83 \mathrm{E}-03$ \\
\hline A6B3 & $8.83 \mathrm{E}-03$ & $4.13 \mathrm{E}-03$ \\
\hline A6B4 & $9.54 \mathrm{E}-03$ & $7.82 \mathrm{E}-03$ \\
\hline A7B1 & $8.94 \mathrm{E}-03$ & $8.32 \mathrm{E}-03$ \\
\hline A7B2 & $7.58 \mathrm{E}-03$ & $5.52 \mathrm{E}-03$ \\
\hline A7B3 & $7.95 \mathrm{E}-03$ & $3.81 \mathrm{E}-03$ \\
\hline A7B4 & $8.67 \mathrm{E}-03$ & $7.50 \mathrm{E}-03$ \\
\hline
\end{tabular}

Table-15: Payoff matrix structured for coalition of players $A$ and $C$

\begin{tabular}{|l|l|l|}
\hline & P1 & P2 \\
\hline A1C1 & $6.50 \mathrm{E}-03$ & $6.04 \mathrm{E}-03$ \\
\hline A1C2 & $6.03 \mathrm{E}-03$ & $8.05 \mathrm{E}-03$ \\
\hline A1C 3 & $6.07 \mathrm{E}-03$ & $8.50 \mathrm{E}-03$ \\
\hline A2C1 & $8.41 \mathrm{E}-03$ & $3.89 \mathrm{E}-03$ \\
\hline A2C2 & $7.93 \mathrm{E}-03$ & $5.90 \mathrm{E}-03$ \\
\hline A2C 3 & $7.98 \mathrm{E}-03$ & $6.35 \mathrm{E}-03$ \\
\hline A3C1 & $8.69 \mathrm{E}-03$ & $5.73 \mathrm{E}-03$ \\
\hline A3C 2 & $8.22 \mathrm{E}-03$ & $7.74 \mathrm{E}-03$ \\
\hline A3C 3 & $8.26 \mathrm{E}-03$ & $8.20 \mathrm{E}-03$ \\
\hline A4C1 & $8.49 \mathrm{E}-03$ & $5.23 \mathrm{E}-03$ \\
\hline A4C2 & $8.01 \mathrm{E}-03$ & $7.23 \mathrm{E}-03$ \\
\hline A4C3 & $8.06 \mathrm{E}-03$ & $7.69 \mathrm{E}-03$ \\
\hline A5C1 & $8.62 \mathrm{E}-03$ & $4.23 \mathrm{E}-03$ \\
\hline A5C2 & $8.14 \mathrm{E}-03$ & $6.24 \mathrm{E}-03$ \\
\hline A5C 3 & $8.19 \mathrm{E}-03$ & $6.69 \mathrm{E}-03$ \\
\hline A6C1 & $8.69 \mathrm{E}-03$ & $5.41 \mathrm{E}-03$ \\
\hline A6C2 & $8.21 \mathrm{E}-03$ & $7.42 \mathrm{E}-03$ \\
\hline A6C 3 & $8.26 \mathrm{E}-03$ & $7.87 \mathrm{E}-03$ \\
\hline A7C1 & $7.81 \mathrm{E}-03$ & $5.09 \mathrm{E}-03$ \\
\hline A7C2 & $7.34 \mathrm{E}-03$ & $7.10 \mathrm{E}-03$ \\
\hline A7C3 & $7.38 \mathrm{E}-03$ & $7.56 \mathrm{E}-03$ \\
\hline
\end{tabular}

Table-16: Payoff matrix structured for coalition of players $B$ and $C$

\begin{tabular}{|l|l|l|}
\hline & P1 & P2 \\
\hline B1C1 & $8.53 \mathrm{E}-03$ & $5.78 \mathrm{E}-03$ \\
\hline B1C2 & $8.05 \mathrm{E}-03$ & $7.79 \mathrm{E}-03$ \\
\hline B1C3 & $8.10 \mathrm{E}-03$ & $8.24 \mathrm{E}-03$ \\
\hline B2C1 & $7.17 \mathrm{E}-03$ & $2.98 \mathrm{E}-03$ \\
\hline B2C2 & $6.69 \mathrm{E}-03$ & $4.99 \mathrm{E}-03$ \\
\hline B2C3 & $6.73 \mathrm{E}-03$ & $5.44 \mathrm{E}-03$ \\
\hline B3C1 & $7.54 \mathrm{E}-03$ & $1.28 \mathrm{E}-03$ \\
\hline B3C2 & $7.06 \mathrm{E}-03$ & $3.29 \mathrm{E}-03$ \\
\hline B3C3 & $7.11 \mathrm{E}-03$ & $3.74 \mathrm{E}-03$ \\
\hline B4C1 & $8.26 \mathrm{E}-03$ & $4.96 \mathrm{E}-03$ \\
\hline B4C2 & $7.78 \mathrm{E}-03$ & $6.97 \mathrm{E}-03$ \\
\hline B4C3 & $7.83 \mathrm{E}-03$ & $7.43 \mathrm{E}-03$ \\
\hline
\end{tabular}


Table-17: Payoff matrix structured for coalition of players $A, B$ and $C$

\begin{tabular}{|l|l|l|}
\hline & P1 & P2 \\
\hline A1B1C1 & $1.13 \mathrm{E}-02$ & $1.05 \mathrm{E}-02$ \\
\hline A1B1C2 & $1.08 \mathrm{E}-02$ & $1.26 \mathrm{E}-02$ \\
\hline A1B1C3 & $1.09 \mathrm{E}-02$ & $1.30 \mathrm{E}-02$ \\
\hline A1B2C1 & $9.97 \mathrm{E}-03$ & $7.74 \mathrm{E}-03$ \\
\hline A1B2C2 & $9.49 \mathrm{E}-03$ & $9.75 \mathrm{E}-03$ \\
\hline A1B2C3 & $9.54 \mathrm{E}-03$ & $1.02 \mathrm{E}-02$ \\
\hline A1B3C1 & $1.03 \mathrm{E}-02$ & $6.04 \mathrm{E}-03$ \\
\hline A1B3C2 & $9.87 \mathrm{E}-03$ & $8.05 \mathrm{E}-03$ \\
\hline A1B3C3 & $9.91 \mathrm{E}-03$ & $8.50 \mathrm{E}-03$ \\
\hline A1B4C1 & $1.11 \mathrm{E}-02$ & $9.73 \mathrm{E}-03$ \\
\hline A1B4C2 & $1.06 \mathrm{E}-02$ & $1.17 \mathrm{E}-02$ \\
\hline A1B4C3 & $1.06 \mathrm{E}-02$ & $1.22 \mathrm{E}-02$ \\
\hline A2B1C1 & $1.32 \mathrm{E}-02$ & $8.39 \mathrm{E}-03$ \\
\hline A2B1C2 & $1.28 \mathrm{E}-02$ & $1.04 \mathrm{E}-02$ \\
\hline A2B1C3 & $1.28 \mathrm{E}-02$ & $1.09 \mathrm{E}-02$ \\
\hline A2B2C1 & $1.19 \mathrm{E}-02$ & $5.59 \mathrm{E}-03$ \\
\hline A2B2C2 & $1.14 \mathrm{E}-02$ & $7.60 \mathrm{E}-03$ \\
\hline A2B2C3 & $1.14 \mathrm{E}-02$ & $8.06 \mathrm{E}-03$ \\
\hline A2B3C1 & $1.22 \mathrm{E}-02$ & $3.89 \mathrm{E}-03$ \\
\hline A2B3C2 & $1.18 \mathrm{E}-02$ & $5.90 \mathrm{E}-03$ \\
\hline A2B3C3 & $1.18 \mathrm{E}-02$ & $6.35 \mathrm{E}-03$ \\
\hline A2B4C1 & $1.30 \mathrm{E}-02$ & $7.58 \mathrm{E}-03$ \\
\hline A2B4C2 & $1.25 \mathrm{E}-02$ & $9.58 \mathrm{E}-03$ \\
\hline A2B4C3 & $1.25 \mathrm{E}-02$ & $1.00 \mathrm{E}-02$ \\
\hline A3B1C1 & $1.35 \mathrm{E}-02$ & $1.02 \mathrm{E}-02$ \\
\hline A3B1C2 & $1.30 \mathrm{E}-02$ & $1.22 \mathrm{E}-02$ \\
\hline A3B1C3 & $1.31 \mathrm{E}-02$ & $1.27 \mathrm{E}-02$ \\
\hline A3B2C1 & $1.22 \mathrm{E}-02$ & $7.44 \mathrm{E}-03$ \\
\hline A3B2C2 & $1.17 \mathrm{E}-02$ & $9.44 \mathrm{E}-03$ \\
\hline A3B2C3 & $1.17 \mathrm{E}-02$ & $9.90 \mathrm{E}-03$ \\
\hline A3B3C1 & $1.25 \mathrm{E}-02$ & $5.73 \mathrm{E}-03$ \\
\hline A3B3C2 & $1.21 \mathrm{E}-02$ & $7.74 \mathrm{E}-03$ \\
\hline A3B3C3 & $1.21 \mathrm{E}-02$ & $8.20 \mathrm{E}-03$ \\
\hline A3B4C1 & $1.33 \mathrm{E}-02$ & $9.42 \mathrm{E}-03$ \\
\hline A3B4C2 & $1.28 \mathrm{E}-02$ & $1.14 \mathrm{E}-02$ \\
\hline A3B4C3 & $1.28 \mathrm{E}-02$ & $1.19 \mathrm{E}-02$ \\
\hline A4B1C1 & $1.33 \mathrm{E}-02$ & $9.73 \mathrm{E}-03$ \\
\hline A4B1C2 & $1.28 \mathrm{E}-02$ & $1.17 \mathrm{E}-02$ \\
\hline A4B1C3 & $1.29 \mathrm{E}-02$ & $1.22 \mathrm{E}-02$ \\
\hline A4B2C1 & $1.20 \mathrm{E}-02$ & $6.93 \mathrm{E}-03$ \\
\hline A4B2C2 & $1.15 \mathrm{E}-02$ & $8.94 \mathrm{E}-03$ \\
\hline A4B2C3 & $1.15 \mathrm{E}-02$ & $9.39 \mathrm{E}-03$ \\
\hline A4B3C1 & $1.23 \mathrm{E}-02$ & $5.23 \mathrm{E}-03$ \\
\hline A4B3C2 & $1.19 \mathrm{E}-02$ & $7.23 \mathrm{E}-03$ \\
\hline A4B3C3 & $1.19 \mathrm{E}-02$ & $7.69 \mathrm{E}-03$ \\
\hline A4B4C1 & $1.31 \mathrm{E}-02$ & $8.91 \mathrm{E}-03$ \\
\hline A4B4C2 & $1.26 \mathrm{E}-02$ & $1.09 \mathrm{E}-02$ \\
\hline A4B4C3 & $1.26 \mathrm{E}-02$ & $1.14 \mathrm{E}-02$ \\
\hline A5B1C1 & $1.34 \mathrm{E}-02$ & $8.73 \mathrm{E}-03$ \\
\hline A5B1C2 & $1.30 \mathrm{E}-02$ & $1.07 \mathrm{E}-02$ \\
\hline A5B2C1 1 & $1.30 \mathrm{E}-02$ & $1.12 \mathrm{E}-02$ \\
\hline A5B2C 3 & $1.21 \mathrm{E}-02$ & $5.93 \mathrm{E}-03$ \\
\hline & $1.17 \mathrm{E}-02$ & $7.94 \mathrm{E}-03$ \\
\hline
\end{tabular}

\begin{tabular}{|l|l|l|}
\hline A5B3C2 & $1.20 \mathrm{E}-02$ & $6.24 \mathrm{E}-03$ \\
\hline A5B3C3 & $1.20 \mathrm{E}-02$ & $6.69 \mathrm{E}-03$ \\
\hline A5B4C1 & $1.32 \mathrm{E}-02$ & $7.92 \mathrm{E}-03$ \\
\hline A5B4C2 & $1.27 \mathrm{E}-02$ & $9.92 \mathrm{E}-03$ \\
\hline A5B4C3 & $1.28 \mathrm{E}-02$ & $1.04 \mathrm{E}-02$ \\
\hline A6B1C1 & $1.35 \mathrm{E}-02$ & $9.91 \mathrm{E}-03$ \\
\hline A6B1C2 & $1.30 \mathrm{E}-02$ & $1.19 \mathrm{E}-02$ \\
\hline A6B1C3 & $1.31 \mathrm{E}-02$ & $1.24 \mathrm{E}-02$ \\
\hline A6B2C1 & $1.22 \mathrm{E}-02$ & $7.11 \mathrm{E}-03$ \\
\hline A6B2C2 & $1.17 \mathrm{E}-02$ & $9.12 \mathrm{E}-03$ \\
\hline A6B2C3 & $1.17 \mathrm{E}-02$ & $9.57 \mathrm{E}-03$ \\
\hline A6B3C1 & $1.25 \mathrm{E}-02$ & $5.41 \mathrm{E}-03$ \\
\hline A6B3C2 & $1.20 \mathrm{E}-02$ & $7.42 \mathrm{E}-03$ \\
\hline A6B3C3 & $1.21 \mathrm{E}-02$ & $7.87 \mathrm{E}-03$ \\
\hline A6B4C1 & $1.32 \mathrm{E}-02$ & $9.09 \mathrm{E}-03$ \\
\hline A6B4C2 & $1.28 \mathrm{E}-02$ & $1.11 \mathrm{E}-02$ \\
\hline A6B4C3 & $1.28 \mathrm{E}-02$ & $1.16 \mathrm{E}-02$ \\
\hline A7B1C1 & $1.26 \mathrm{E}-02$ & $9.60 \mathrm{E}-03$ \\
\hline A7B1C2 & $1.22 \mathrm{E}-02$ & $1.16 \mathrm{E}-02$ \\
\hline A7B1C3 & $1.22 \mathrm{E}-02$ & $1.21 \mathrm{E}-02$ \\
\hline A7B2C1 & $1.13 \mathrm{E}-02$ & $6.80 \mathrm{E}-03$ \\
\hline A7B2C2 & $1.08 \mathrm{E}-02$ & $8.80 \mathrm{E}-03$ \\
\hline A7B2C 3 & $1.08 \mathrm{E}-02$ & $9.26 \mathrm{E}-03$ \\
\hline A7B3C1 & $1.17 \mathrm{E}-02$ & $5.09 \mathrm{E}-03$ \\
\hline A7B3C2 & $1.12 \mathrm{E}-02$ & $7.10 \mathrm{E}-03$ \\
\hline A7B3C3 & $1.12 \mathrm{E}-02$ & $7.56 \mathrm{E}-03$ \\
\hline A7B4C1 & $1.24 \mathrm{E}-02$ & $8.78 \mathrm{E}-03$ \\
\hline A7B4C2 & $1.19 \mathrm{E}-02$ & $1.08 \mathrm{E}-02$ \\
\hline A7B4C3 & $1.19 \mathrm{E}-02$ & $1.12 \mathrm{E}-02$ \\
\hline
\end{tabular}

The optimal game values are obtained as follow: $v(\{A, B\})=0.00907, v(\{A, C\})=0.00821, v(\{B, C\})$ $=0.00812, v(\{A, B, C\})=0.01275$

Based on the value of the game from the payoff matrices in Tables 11 to 17 , the characteristic functions are calculated and tabulated in Table-18. The characteristic funcions of the game designed for coalitions among player A, player B and player C are shown in the table below:

Table-18: Characteristic function \begin{tabular}{|c|c|}
\hline Characteristic Function & Value \\
\hline
\end{tabular}

\begin{tabular}{|c|c|}
\hline$v(\{\varnothing\})$ & 0.00000 \\
\hline$v(\{A\})$ & 0.00452 \\
\hline$v(\{B\})$ & 0.00450 \\
\hline$v(\{C\})$ & 0.00334 \\
\hline$v(\{A B\})$ & 0.00907 \\
\hline$v(\{A C\})$ & 0.00821 \\
\hline$v(\{B C\})$ & 0.00812 \\
\hline$v(\{A B C\})$ & 0.01275 \\
\hline
\end{tabular}

\section{RESULTS AND DISCUSSION}

The characteristic functions from Table-10 and Table-18 are substituted into Shapley value equation (3) to obtain the marginal contribution for each stock. The marginal contribution for each player, on average, increases the payoff. This shows the bargaining value 
for each player to join the coalitions. The results are in the Shapley vector form for each election phase as follows:

For the $13^{\text {th }}$ general election $\mu_{i}:(0.001895,0.002035,0.00116)$

The results for Shapley value for player A (financial services sector), player B (consumer products and services sector) and player $\mathrm{C}$ (telecommunications and media sector) are 0.001895, 0.002035 and 0.00116 respectively. As normalisation of the Shapley vector values, the percentages are as follows:

$$
P(A)=37 \%, P(B)=40 \%, P(C)=23 \%
$$

$\begin{array}{ccc}\text { The percentages of financial services, } & \text { s } \\ \text { consumer products and services, and }\end{array}$ telecommunications and media sectors are $37 \%, 40 \%$ and $23 \%$ respectively in GE13 period.

For the $14^{\text {th }}$ general election

$$
\mu_{i}:(0.004623,0.004568,0.003558)
$$

The results for Shapley value for player A (financial services sector), player B (consumer products and services sector) and player $\mathrm{C}$ (telecommunications and media sector) are $0.004623,0.004568$ and 0.003558 respectively. As normalisation of the Shapley vector values, the percentages are as follows:

$$
P(A)=36 \%, P(B)=36 \%, P(C)=28 \%
$$

The percentages of financial services, consumer products and services, and telecommunications and media sectors are 36\%, 36\% and $28 \%$ respectively in GE14 period.

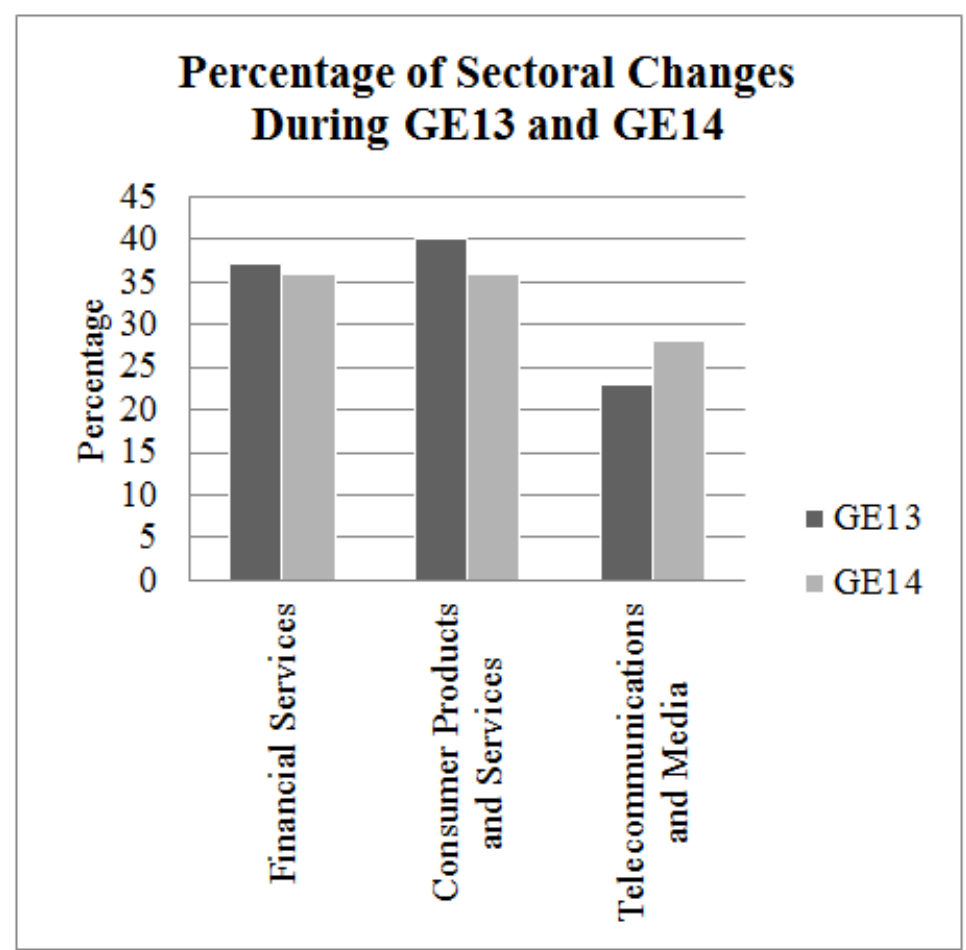

Fig-1: Percentages of sectoral changes during GE13 and GE14

The bar graph represents the percentage comparison between two periods of general elections in Malaysia with three types of sectors in 2013 and 2018. In GE13, the best strategy is $37 \%$ from the financial services sector, $40 \%$ from consumer products and services sector, and $23 \%$ from the telecommunications and media sector. In contrast, during GE14, the best strategy is $36 \%$ from both the financial services and consumer products and services sectors, and $28 \%$ from telecommunications and media. Financial services decreased its share very slightly from $37 \%$ during GE13, to provide $36 \%$ in the next 5 years. The consumer products and services sector have the highest percentage although it decreased from $40 \%$ in GE13 to $36 \%$ in GE14. The telecommunications and media sector in increased its proportion to $28 \%$ in 2018 from $23 \%$ during the previous general election. All sectors except telecommunications and media showed a decrease in percentage in coalition after the new government ruled the country for 6 months.

\section{CONCLUSION}

Game theory is one of the solutions to decision making problems. Based on the Shapley value, the sectoral strategy changes after GE14 in Malaysia were compared to GE13. It has been demonstrated that there is an impact from the political changes on the market. The study can be further used to suggest an optimal portfolio selection to investors when political changes occur. 


\section{REFERENCE}

1. Bodie, Z., Kane, A., \& Marcus, A. J. (2014). Investments (Tenth). McGraw-Hill Education.

2. Liew, V., Sen, K., \& Rowland, R. (2016). The Effect of Malaysia General Election on Stock Market Returns. SpringerPlus. https://doi.org/10.1186/s40064-016-3648-5

3. Markowitz, H. (1952). Portfolio Selection. The Journal of Finance, 7(1), 77-91.

4. Osborne, M. J. (2004). An Introduction to Game Theory. Oxford University Press.

5. Floros, C. (2008). The Influence of the Political Elections on the Course of the Athens Stock Exchange. Managerial Finance, 34(7), 479-488.

6. Abidin, S., Old, C., \& Martin, T. (2010). International Review of Business Research Papers Effects of New Zealand General Elections on Stock Market Returns. International Review of Business Research Papers, 6(6), 1-12.

7. Smales, L. A. (2014). Political Uncertainty and Financial Market Uncertainty in An Australian Context. Journal of International Financial Markets, Institutions \& Money, 32, 415-435.

8. Lehkonen, H., \& Heimonen, K. (2015). Democracy, Political Risks and Stock Market Performance. Journal of International Money and
Finance, 59, 77-99.

9. Lean, H. H., \& Yeap, G. P. (2016). Asymmetric Effect of Political Elections on Stock Returns and Volatility in Malaysia. Information Efficiency and Anomalies in Asian Equity Markets: Theories and Evidence, 228-242.

10. Chavali, K., Alam, M., \& Rosario, S. (2020). Stock market response to elections: An event study method. Journal of Asian Finance, Economics and Business, 7(5), 9-08.

11. Kocak, H. (2014). Canonical Coalition Game Theory for Optimal Portfolio Selection. Asian Economic and Financial Review, 4(9), 1254-1259.

12. Tataei, P., Roudposhti, F. R., Nikoumaram, H., \& Hafezolkotob, A. (2018). Outperforming the Market Portfolio Using Coalitional Game Theory Approach. 3(05), 145-155.

13. Ozkan, N. (2015). Analysis of Sectoral Performance in Borsa Istanbul: A Game Theoretic Approach. The Business and Management Revieiw, 6(3), 22-23.

14. Slišković, M., \& Škrinjarić, T. (2019). Asset Risk Evaluation Using Shapley Value. In Šimurina, J., Braje, I. N., \& Pavić, I. (Eds.), Proceedings of FEB Zagreb 10th International Odyssey Conference on Economics and Business. 509-518. 